Article

\title{
Development of Technetium-99m-Labeled BODIPY-Based Probes Targeting Lipid Droplets Toward the Diagnosis of Hyperlipidemia-Related Diseases
}

\author{
Yoichi Shimizu ${ }^{1,2, *,+}$, Keiichi Tanimura ${ }^{1,+}$, Shimpei Iikuni ${ }^{1}$, Hiroyuki Watanabe ${ }^{1}$, Hideo Saji ${ }^{1}$ \\ and Masahiro Ono ${ }^{1, *}$ \\ 1 Department of Patho-Functional Bioanalysis, Graduate School of Pharmaceutical Sciences, Kyoto University, \\ 46-29, Yoshida Shimoadachi-cho, Sakyo-ku, Kyoto 606-8501, Japan; \\ tanimura.keiichi.35z@st.kyoto-u.ac.jp (K.T.); iikuni@pharm.kyoto-u.ac.jp (S.I.); \\ hwatanabe@pharm.kyoto-u.ac.jp (H.W.); hsaji@pharm.kyoto-u.ac.jp (H.S.) \\ 2 Department of Diagnostic Imaging and Nuclear Medicine, Graduate School of Medicine, Kyoto University, \\ 54 Kawahara-cho, Shogoin, Sakyo-ku, Kyoto 606-8507, Japan \\ * Correspondence: yoichis@kuhp.kyoto-u.ac.jp (Y.S.); ono@pharm.kyoto-u.ac.jp (M.O.); \\ Tel.: +81-75-751-3760 (Y.S.); +81-75-753-4556 (M.O.) \\ + These authors contributed equally to this manuscript.
}

Received: 30 April 2019; Accepted: 17 June 2019; Published: 19 June 2019

\begin{abstract}
Hyperlipidemia causes systemic lipid disorder, which leads to hepatic steatosis and atherosclerosis. Thus, it is necessary to detect these syndromes early and precisely to improve prognosis. In the affected regions, abnormal formation and growth of lipid droplets is observed; therefore, lipid droplets may be a suitable target for the diagnosis of hyperlipidemia-related syndromes. In this study, we designed and synthesized [ $\left.{ }^{99 \mathrm{~m}} \mathrm{Tc}\right] \mathrm{Tc}-\mathrm{BOD}$ and $\left[{ }^{99 \mathrm{~m}} \mathrm{Tc}\right] \mathrm{Tc}-\mathrm{MBOD}$ composed of one technetium-99m and two BODIPY scaffolds with hydroxamamide (Ham) or $N$-methylated hydroxamamide (MHam) in radiochemical yields of 54 and 35\%, respectively, with a radiochemical purity of over $95 \%$. $\left.{ }^{99 \mathrm{~m}} \mathrm{Tc}\right] \mathrm{Tc}-\mathrm{BOD}$ showed significantly higher accumulation levels in foam cells than in non-foam cells (foam cells: $213.8 \pm 64.8$, non-foam cell: $126.2 \pm 26.9 \%$ dose/mg protein, $p<0.05) 2 \mathrm{~h}$ after incubation. In contrast, $\left[{ }^{99 \mathrm{~m}} \mathrm{Tc}\right] \mathrm{Tc}-\mathrm{MBOD}$ showed similar accumulation levels in foam cells and non-foam cells (foam cells: $92.2 \pm 23.3$, non-foam cell: $83.8 \pm 19.8 \%$ dose/mg protein). In normal mice, [ $\left.{ }^{99 \mathrm{~m}} \mathrm{Tc}\right] \mathrm{Tc}-\mathrm{BOD}$ exhibited gradual blood clearance (0.5 h: $4.98 \pm 0.35,6 \mathrm{~h}: 1.94 \pm 0.12$ $\% \mathrm{ID} / \mathrm{g})$ and relatively high accumulation in the liver $6 \mathrm{~h}$ after administration $(15.22 \pm 1.72 \% \mathrm{ID} / \mathrm{g})$. Therefore, $\left[{ }^{99 \mathrm{~m}} \mathrm{Tc}\right] \mathrm{Tc}-\mathrm{BOD}$ may have potential as an imaging probe for detecting lipid droplets in disease lesions of hyperlipidemia.
\end{abstract}

Keywords: technetium-99m; hyperlipidemia; hydroxamamide; BODIPY

\section{Introduction}

Hyperlipidemia or dyslipidemia is a chronic lipid disorder in which the lipid content in blood, such as cholesterol, increases abnormally [1]. This disease causes systemic lipid disorder, with manifestations such as fatty infiltration of the liver and lipid deposition in vessels, which leads to hepatic steatosis and atherosclerosis [2,3]. Such hyperlipidemia-related syndromes are risk factors for severe diseases, such as liver dysfunction, liver cancer, and cerebral and myocardial infarction [4,5]. Therefore, it is necessary to detect these syndromes early and precisely to improve prognosis.

Lipid droplets are an intracellular organelle where neutral lipids of cells are stored [6,7]. In hepatic steatosis and atherosclerosis lesions, the abnormal formation and growth of lipid droplets is observed, 
and this is suspected to play a key role in the progression of these syndromes [8,9]. Thus, abnormally enlarged lipid droplets may be a suitable target for the diagnosis of hyperlipidemia-related syndromes. To detect lipid droplets, several hydrophobic dyes, including fluorescent probes such as Nile red and boron dipyrromethene (BODIPY), have been reported for histological or microscopic visualization [10,11]. Among these dyes, BODIPY493/503 demonstrated specific staining of lipid droplets and has been examined as an in vitro staining agent for the detection of lipid droplets in living cells [12]. For non-invasive in vivo imaging and clinical diagnosis, imaging modalities, such as positron emission tomography (PET), single photon emission computed tomography (SPECT), and magnetic resonance imaging (MRI), are widely used [13]. Although several MRI probes based on BODIPY scaffolds have been developed for the diagnosis of vulnerable plaques [14,15], no PET or SPECT imaging probe targeting lipid droplets has been reported to exist.

Therefore, we aimed to develop novel nuclear medical imaging probes based on BODIPY scaffolds for the visualization of lipid droplet regions in hyperlipidemia-related syndrome. Technetium-99m $\left({ }^{99 m} \mathrm{Tc}\right)$ is one of the major radioisotopes for clinical SPECT imaging because the gamma rays emitted from ${ }^{99} \mathrm{~m}$ Tc with a photon energy of $141-\mathrm{keV}$ are readily detectable by the SPECT scanner, and ${ }^{99 \mathrm{~m}} \mathrm{Tc}$ is easily produced using a molybdenum-99/technetium-99m generator. To label the BODIPY scaffold with ${ }^{99 m} \mathrm{Tc}$, we selected two types of chelators: hydroxamamide (Ham) and N-methylated hydroxamamide (MHam). Ham is a thiol-free chelating agent that produces the ${ }^{99 \mathrm{~m}} \mathrm{Tc}$-complex with a high radiochemical yield under moderate reaction conditions $[16,17]$. In addition, Ham forms the ${ }^{99 \mathrm{~m}}$ Tc-complex with a metal-to-ligand ratio of 1:2, which makes it possible to easily produce ${ }^{99 \mathrm{~m}} \mathrm{Tc}$-labeled compounds with a bivalent targeting scaffold [18,19]. MHam is also a thiol-free chelating agent with similar properties to Ham, and the 99m Tc-complex with MHam exhibited higher stability in murine plasma than that with Ham [20,21].

In this study, we synthesized [ $\left.{ }^{99 \mathrm{~m}} \mathrm{Tc}\right] \mathrm{Tc}-\mathrm{Ham}-\mathrm{BODIPY}\left(\left[{ }^{99 \mathrm{~m}} \mathrm{Tc}\right] \mathrm{Tc}-\mathrm{BOD}\right)$ and [ $\left.{ }^{99 \mathrm{~m}} \mathrm{Tc}\right] \mathrm{Tc}-\mathrm{MHam}-\mathrm{BODIPY}$ $\left(\left[{ }^{99 m} \mathrm{Tc}\right] \mathrm{Tc}-\mathrm{MBOD}\right)$ and evaluated their effectiveness for the detection of lipid droplets.

\section{Results}

\subsection{Chemistry}

The synthesis of Ham-BODIPY (2) and MHam-BODIPY (5) is outlined in Scheme 1. The BODIPY derivative 1 was synthesized thorugh the reaction of 4-formylbenzonitrile, 2,4-dimethylpyrrole, and boron trifluoride diethyl ether complex. A Ham group was introduced into 1 through a reaction with hydroxylamine, performed according to a previously reported method This produced Ham-BODIPY (2) from 4-formylbenzonitrile, with a yield of 9.7\% [18]. MHam-BODIPY (5) was prepared in three steps from $\mathbf{2}$. Reaction of $\mathbf{2}$ with 1,1-carbonyldiimidazole provided compound 3 in DMSO. Then, 3 was methylated by iodomethane to give compound 4 . Finally, 4 was decyclized by heating in an alkaline solution to MHam-BODIPY (5), with the overall yield of 1.0\% from 4-formylbenzonitrile.
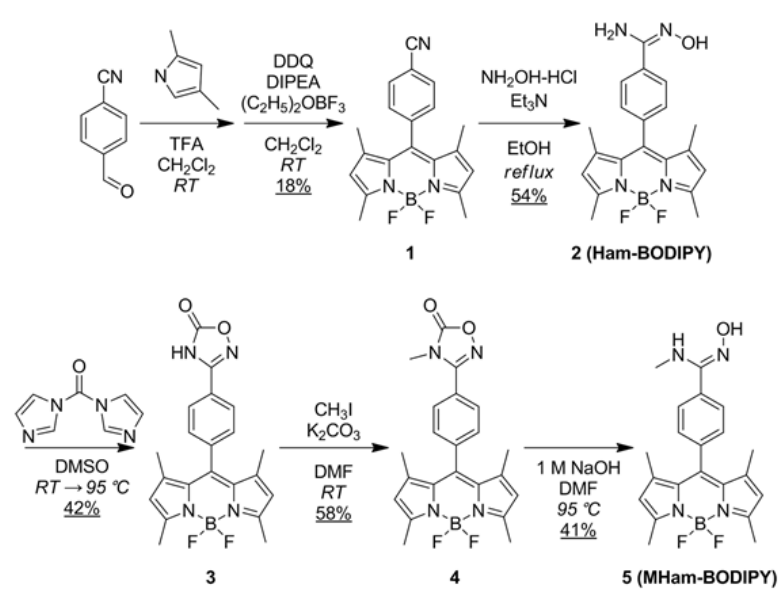

Scheme 1. Synthetic route for Ham-BODIPY and MHam-BODIPY. 


\subsection{Radiolabeling}

The ${ }^{99 \mathrm{~m}} \mathrm{Tc}$ labeling reaction was performed by the complexation reaction using Ham-BODIPY (2) or MHam-BODIPY (5), ${ }^{99 \mathrm{~m}} \mathrm{Tc}$ pertechnetate, and tin(II) tartrate hydrate as a reducing agent (Scheme 2). [ $\left.{ }^{99 \mathrm{~m}} \mathrm{Tc}\right] \mathrm{Tc}-\mathrm{BOD}$ and $\left[{ }^{99 \mathrm{~m}} \mathrm{Tc}\right] \mathrm{Tc}-\mathrm{MBOD}$ were obtained in a radiochemical yield of a 54 and $35 \%$, respectively, with a radiochemical purity of over $95 \%$ (Figure 1 ).
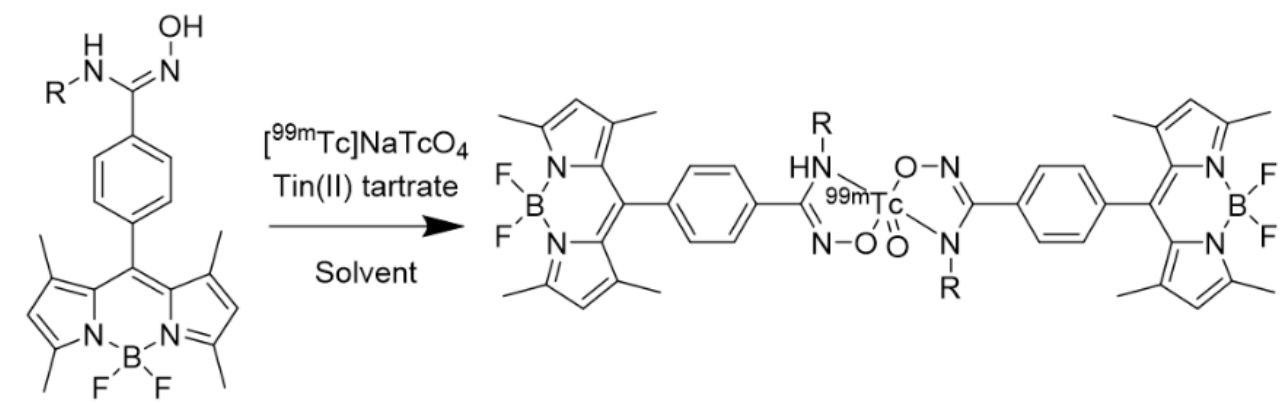

$$
\begin{array}{ll}
\mathrm{R}=\mathrm{H} & : \mathbf{2} \text { (Ham-BODIPY) } \\
\mathrm{R}=\mathrm{CH}_{3}: \mathbf{5} \text { (MHam-BODIPY) }
\end{array}
$$$$
\begin{aligned}
& \mathbf{R}=\mathbf{H} \quad:\left[{ }^{99 \mathrm{~m}} \mathrm{Tc}\right] \mathrm{Tc}-\mathrm{BOD} \\
& \mathrm{R}=\mathrm{CH}_{3}:\left[{ }^{99 \mathrm{~m}} \mathrm{Tc}\right] \mathrm{Tc}-\mathrm{MBOD}
\end{aligned}
$$

Scheme 2. ${ }^{99} \mathrm{~m}$ Tc labeling route and proposed chemical structures of $\left[{ }^{99 \mathrm{~m}} \mathrm{Tc}\right] \mathrm{Tc}-\mathrm{BOD}$ and $\left[{ }^{99 \mathrm{~m}} \mathrm{Tc}\right] \mathrm{Tc}-\mathrm{MBOD}$.
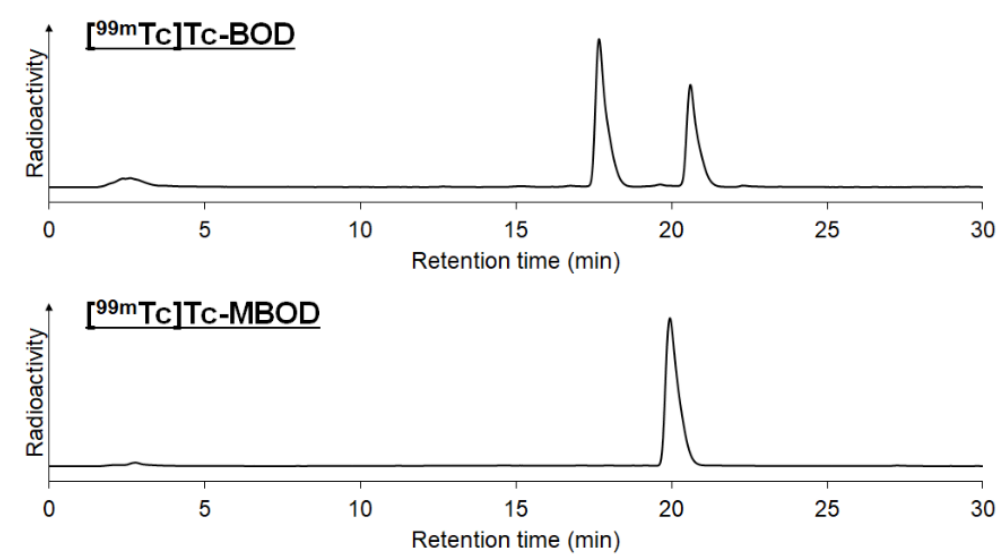

Figure 1. Radiochromatograms for [ $\left.{ }^{99 \mathrm{~m}} \mathrm{Tc}\right] \mathrm{Tc}-\mathrm{BOD}$ and $\left[{ }^{99 \mathrm{~m}} \mathrm{Tc}\right] \mathrm{Tc}-\mathrm{MBOD}$ after purification.

\subsection{In Vitro Cellular Uptake Study}

The cellular uptake of $\left[{ }^{99 \mathrm{~m}} \mathrm{Tc}\right] \mathrm{Tc}-\mathrm{BOD}$ and $\left[{ }^{99 \mathrm{~m}} \mathrm{Tc}\right] \mathrm{Tc}-\mathrm{MBOD}$ is expressed as the \%dose/mg protein (Figure 2A), and foam cell formation was confirmed using Oil red O staining (Figure 2B,C). The cellular uptake of [ $\left.{ }^{99 \mathrm{~m}} \mathrm{Tc}\right] \mathrm{Tc}-\mathrm{BOD}$ into foam cells was significantly higher than that into non-foam cells (foam cell: $213.8 \pm 64.8$, non-foam cell: $126.2 \pm 26.9 \%$ dose/mg protein, $p<0.05)$. On the other hand, the difference between the uptake of [ $\left.{ }^{99 \mathrm{~m}} \mathrm{Tc}\right] \mathrm{Tc}-\mathrm{MBOD}$ into foam cells and non-foam cells was not significant (foam cell: $92.2 \pm 23.3$, non-foam cell: $83.8 \pm 19.8 \%$ dose/mg protein) (Figure $2 \mathrm{~A}$ ).

\subsection{Stability in Murine Plasma}

The in vitro stability of $\left[{ }^{99 \mathrm{~m}} \mathrm{Tc}\right] \mathrm{Tc}-\mathrm{BOD}$ was evaluated by incubation in murine plasma at $37^{\circ} \mathrm{C}$ for $6 \mathrm{~h}$. [ $\left.{ }^{99 \mathrm{~m}} \mathrm{Tc}\right] \mathrm{Tc}-\mathrm{BOD}$ had a radiochemical purity of over $80 \%$ in murine plasma $6 \mathrm{~h}$ after incubation (Figure 3). 

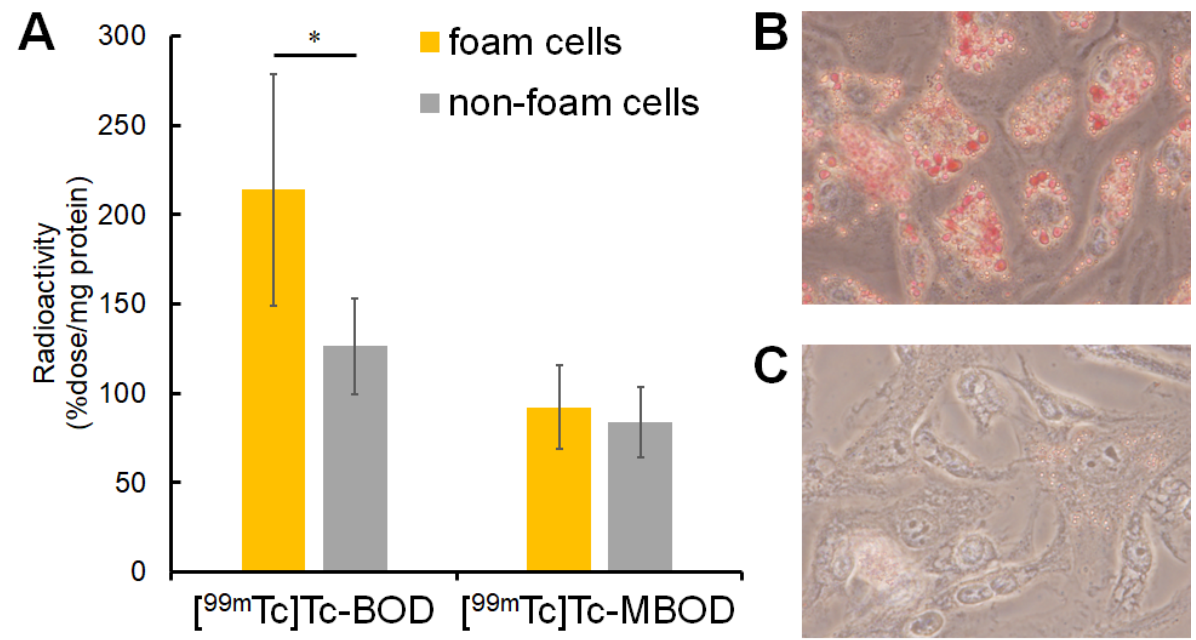

Figure 2. (A) In vitro cellular uptake of [ $\left.{ }^{99 \mathrm{~m}} \mathrm{Tc}\right] \mathrm{Tc}-\mathrm{BOD}$ and $\left[{ }^{99 \mathrm{~m}} \mathrm{Tc}\right] \mathrm{Tc}-\mathrm{MBOD}$. Values are expressed as the mean \pm standard error of six independent experiments. ${ }^{*} p<0.05$ (Student's $t$-test). (B,C) Oil red O staining images of (B) foam cells and (C) non-foam cells. Deep red staining of $\mathbf{B}$ indicates the rich formation of lipid droplets.

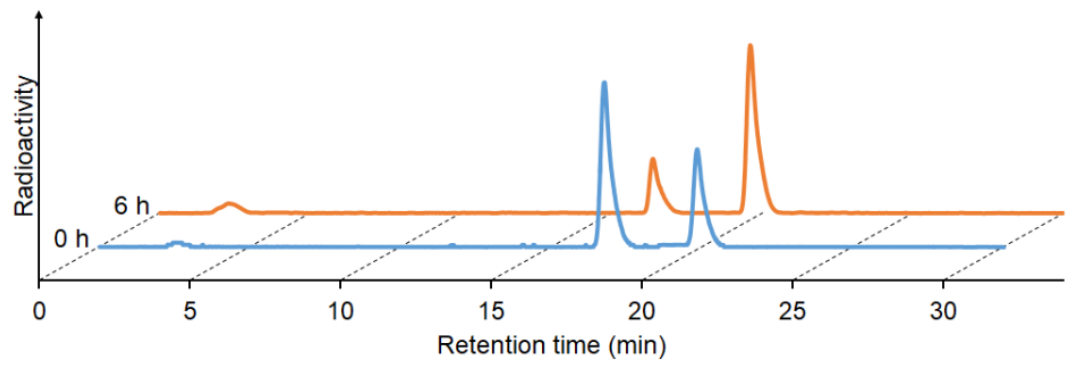

Figure 3. In vitro stability of $\left[{ }^{99 \mathrm{~m}} \mathrm{Tc}\right] \mathrm{Tc}-\mathrm{BOD}$ in murine plasma. $\left[{ }^{99 \mathrm{~m}} \mathrm{Tc}\right] \mathrm{Tc}-\mathrm{BOD}$ had a radiochemical purity of over $80 \%$ in murine plasma $6 \mathrm{~h}$ after incubation.

\subsection{In Vivo Biodistribution}

The uptake of $\left[{ }^{99 m} \mathrm{Tc}\right] \mathrm{Tc}-\mathrm{BOD}$ in each organ was expressed as the $\% \mathrm{ID} / \mathrm{g}$, except for in the stomach, which was expressed as the \%ID (Table 1). [ $\left.{ }^{99 \mathrm{~m}} \mathrm{Tc}\right] \mathrm{Tc}-\mathrm{BOD}$ exhibited gradual blood clearance (0.5 h: $4.98 \pm 0.35,6 \mathrm{~h}: 1.94 \pm 0.12 \% \mathrm{ID} / \mathrm{g})$ and demonstrated relatively higher uptake in the liver $(6 \mathrm{~h}$ : $15.22 \pm 1.72 \% \mathrm{ID} / \mathrm{g})$ and stomach ( $6 \mathrm{~h}: 25.25 \pm 5.30 \% \mathrm{ID})$.

Table 1. Biodistribution of [ $\left.{ }^{99 \mathrm{~m}} \mathrm{Tc}\right] \mathrm{Tc}-\mathrm{BOD}$ in normal (ddY) mice.

\begin{tabular}{ccccc}
\hline \multirow{2}{*}{ Organ } & \multicolumn{4}{c}{ Time after Injection } \\
\cline { 2 - 5 } & $\mathbf{0 . 5} \mathbf{h}$ & $\mathbf{1} \mathbf{h}$ & $\mathbf{3} \mathbf{~ h}$ & $\mathbf{6} \mathbf{~ h}$ \\
\hline Blood & $4.98 \pm 0.35$ & $3.33 \pm 0.29$ & $2.70 \pm 0.33$ & $1.94 \pm 0.12$ \\
Spleen & $6.46 \pm 1.09$ & $5.47 \pm 1.34$ & $5.44 \pm 0.79$ & $5.58 \pm 0.65$ \\
Pancreas & $1.41 \pm 0.15$ & $1.08 \pm 0.17$ & $0.96 \pm 0.16$ & $0.79 \pm 0.10$ \\
Stomach* & $23.87 \pm 2.56$ & $28.77 \pm 3.52$ & $29.80 \pm 3.48$ & $25.25 \pm 5.30$ \\
Intestine & $2.03 \pm 0.31$ & $2.94 \pm 0.41$ & $5.28 \pm 0.37$ & $7.90 \pm 1.72$ \\
Kidney & $2.43 \pm 0.30$ & $2.16 \pm 0.35$ & $2.07 \pm 0.26$ & $2.07 \pm 0.39$ \\
Liver & $17.43 \pm 1.87$ & $14.99 \pm 2.63$ & $15.93 \pm 1.32$ & $15.22 \pm 1.72$ \\
Heart & $1.96 \pm 0.15$ & $1.22 \pm 0.14$ & $1.19 \pm 0.13$ & $0.89 \pm 0.08$ \\
Lung & $8.85 \pm 2.42$ & $4.80 \pm 0.82$ & $3.22 \pm 0.70$ & $2.33 \pm 0.44$ \\
\hline
\end{tabular}

Values are expressed as the \% injected dose per gram $(\% \mathrm{ID} / \mathrm{g})$ of organ tissue. Each value is the mean \pm standard deviation of five mice at each interval. *Values are expressed as the \% injected dose (\%ID). 


\section{Discussion}

In this study, we developed novel ${ }^{99 \mathrm{~m}} \mathrm{Tc}$ labeled probes, $\left[{ }^{99 \mathrm{~m}} \mathrm{Tc}\right] \mathrm{Tc}-\mathrm{BOD}$ and $\left[{ }^{99 \mathrm{~m}} \mathrm{Tc}\right] \mathrm{Tc}-\mathrm{MBOD}$, for the purpose of imaging of lipid droplets. Ham-BODIPY (2) and MHam-BODIPY (5), the precursors of [ $\left.{ }^{99 \mathrm{~m}} \mathrm{Tc}\right] \mathrm{Tc}-\mathrm{BOD}$ and $\left[{ }^{99 \mathrm{~m}} \mathrm{Tc}\right] \mathrm{Tc}-\mathrm{MBOD}$, respectively, were synthesized with total yields of 9.7 and $1.0 \%$, respectively (Scheme 1). [ $\left.{ }^{99 \mathrm{~m}} \mathrm{Tc}\right] \mathrm{Tc}-\mathrm{BOD}$ and $\left[{ }^{99 \mathrm{~m}} \mathrm{Tc}\right] \mathrm{Tc}-\mathrm{MBOD}$ were obtained under moderate conditions (at room temperature for $10 \mathrm{~min}$ ) with radiochemical yields of 54 and $35 \%$, respectively. In general, the chelation reactions of technetium-99m and hydroxamamide/ $\mathrm{N}$-methylated hydroxamamide have been evaluated only by confirming the disappearance of the peak derived from $\left[{ }^{99} \mathrm{~m} \mathrm{Tc}_{\mathrm{TcO}}{ }_{4}^{-}\right.$in HPLC analysis. This is because it remains challenging to synthesize the analogues of the rhenium hydroxamamide/N-methylated hydroxamamide complexes [18,19]. In this study, when the reaction mixture of Ham-BODIPY (2) was analyzed using RP-HPLC, two ${ }^{99 \mathrm{~m}}$ Tc-labeled compounds were found at retention times of 17.7 and $20.6 \mathrm{~min}\left(\left[{ }^{99 \mathrm{~m}} \mathrm{Tc}\right] \mathrm{Tc}-\mathrm{BOD}\right)$, which were different from the retention time of $\left[{ }^{99 m} \mathrm{Tc}\right] \mathrm{NaTcO}_{4}$ (Supplementary Figure S1E). This result was consistent with previous reports on ${ }^{99 \mathrm{~m}} \mathrm{Tc}-$ Ham complexes, suggesting that two isomers of $\left[{ }^{99 \mathrm{~m}} \mathrm{Tc}\right] \mathrm{Tc}-\mathrm{BOD}$ were produced by the ${ }^{99 \mathrm{~m}} \mathrm{Tc}$ complexation reaction using Ham (Figure 1) [18]. There is no report stating that BODIPY itself is a ligand or substrate for specific receptors or enzymes, and it is suspected to be delivered to lipid droplets via its lipophilicity. Thus, we considered the two isomers of $\left[{ }^{99 \mathrm{~m}} \mathrm{Tc}\right] \mathrm{Tc}-\mathrm{BOD}$ not to have different properties for targeting lipid droplets, and we used a mixture of both isomers for the in vitro and in vivo evaluations of $\left[{ }^{99 \mathrm{~m}} \mathrm{Tc}\right] \mathrm{Tc}-\mathrm{BOD}$. On the other hand, analysis of the ${ }^{99 \mathrm{~m}} \mathrm{Tc}$ complexation reaction with MHam-BODIPY (5) by RP-HPLC revealed a single radioactive peak at a retention time of $20.0 \mathrm{~min}$ $\left(\left[{ }^{99 \mathrm{~m}} \mathrm{Tc}\right] \mathrm{Tc}-\mathrm{MBOD}\right)$. This suggested that $\mathrm{N}$-methylation of Ham is a useful strategy to obtain a single ${ }^{99 \mathrm{~m}} \mathrm{Tc}-\mathrm{MHam}$ complex by preventing isomerism, as described in a previous report [20].

We next performed an in vitro study to elucidate whether [ $\left.{ }^{99 \mathrm{~m}} \mathrm{Tc}\right] \mathrm{Tc}-\mathrm{BOD}$ and $\left[{ }^{99 \mathrm{~m}} \mathrm{Tc}\right] \mathrm{Tc}-\mathrm{MBOD}$ are able to detect lipid droplets. As lipid-rich model cells, we selected foam macrophages, which are used for studies on atherosclerosis [22,23]. Previously reported optical imaging probes have hydrophobic characteristics to detect lipid droplets [10]. [99m Tc]Tc-BOD accumulation in foam cells was significantly higher than that in non-foam cells, suggesting that $\left[{ }^{99 \mathrm{~m}} \mathrm{Tc}\right] \mathrm{Tc}-\mathrm{BOD}$ may be taken up specifically by cells with lipid droplets. However, [ $\left.{ }^{99 \mathrm{~m}} \mathrm{Tc}\right] \mathrm{Tc}-\mathrm{MBOD}$ accumulated similarly in both foam cells and non-foam cells. The reason as to why $\left[{ }^{99 \mathrm{~m}} \mathrm{Tc}\right] \mathrm{Tc}-\mathrm{MBOD}$ did not accumulate in foam cells specifically is still unclear, but the hydrophobicity of the BODIPY scaffold may not be as necessary for specific accumulation in foam cells.

We next evaluated the distribution of $\left[{ }^{99 \mathrm{~m}} \mathrm{Tc}\right] \mathrm{Tc}-\mathrm{BOD}$ in normal (ddY) mice. In murine plasma, although the rate of the two $\left[{ }^{99 \mathrm{~m}} \mathrm{Tc}\right] \mathrm{Tc}-\mathrm{BOD}$ isoforms was changed, $\left[{ }^{99 \mathrm{~m}} \mathrm{Tc}\right] \mathrm{Tc}-\mathrm{BOD}$ exhibited high stability for $6 \mathrm{~h}$, which is suitable for in vivo imaging (Figure 3). In normal mice, $\left[{ }^{99 \mathrm{~m}} \mathrm{Tc}\right] \mathrm{Tc}-\mathrm{BOD}$ levels gradually decreased in the blood, which is suitable for SPECT imaging (Table 1). However, [ $\left.{ }^{99 \mathrm{~m}} \mathrm{Tc}\right] \mathrm{Tc}-\mathrm{BOD}$ also had relatively high uptake and retention in the stomach and liver. To visualize hepatic steatosis, $\left[{ }^{99 \mathrm{~m}} \mathrm{Tc}\right] \mathrm{Tc}-\mathrm{BOD}$ (with its high uptake and retention in the liver) is not suitable. One strategy to solve this problem is to connect two Ham groups with a propylene linker, which was reported to reduce liver retention in a previous report [24]. Regarding the diagnosis of atherosclerosis, some previously reported probes also had high accumulation in the liver [25]. Therefore, [ $\left.{ }^{99 \mathrm{~m}} \mathrm{Tc}\right] \mathrm{Tc}-\mathrm{BOD}$ holds potential for imaging lipid droplets in atherosclerotic lesions.

Several kinds of probes labeled with fluorine-18 and iodine-123/125 have been reported as radiolabeled probes with a BODIPY scaffold [26-28]. However, fluorine-18 is a cyclotron-produced isotope; this limits the production of fluorine-18-labeled probes because installation of a cyclotron system is expensive and requires a large facility. On the other hand, ${ }^{99 \mathrm{~m}} \mathrm{Tc}$ is easily produced using a molybdenum-99/technetium-99m generator without a large facility, and probes labeled with ${ }^{99 \mathrm{~m}} \mathrm{Tc}$ can be produced via a one-step reaction with ${ }^{99 \mathrm{~m}} \mathrm{Tc}$. Some BODIPY-based compounds labeled with ${ }^{99} \mathrm{~m}$ Tc have been reported [11]. Compared with those compounds, the radiolabeling condition of $\left[{ }^{99 m} \mathrm{Tc}\right] \mathrm{Tc}-\mathrm{BOD}$ is mild (only requiring incubation for $10 \mathrm{~min}$ at room temperature), which makes it 
more convenient for the acquisition of ${ }^{99 \mathrm{~m}} \mathrm{Tc}$-labeled BODIPY. Thus, $\left[{ }^{99 \mathrm{~m}} \mathrm{Tc}\right] \mathrm{Tc}-\mathrm{BOD}$ may be useful as a radiolabeled probe with a BODIPY scaffold.

A multimodal imaging technique combining nuclear medical imaging and fluorescence imaging has been developed. It is expected to integrate each advantage, such as a high spatial resolution in fluorescence imaging and a high signal permeability in nuclear medical imaging [29]. The BODIPY scaffold we used as a ligand targeting lipid droplets has suitable properties for fluorescence imaging (Supplementary Table S1 and Figure S2). Therefore, we tried to perform a microscopic fluorescence imaging study. In this study, we used Ham-BODIPY instead of [ $\left.{ }^{99 m} \mathrm{Tc}\right] \mathrm{Tc}-\mathrm{BOD}$ because it is quite difficult to acquire enough ${ }^{99 \mathrm{~m}}$ Tc-radiolabeled compound (i.e., approximately a femtomole level) for fluorescence imaging (Supplementary Figure S3). As a result, a high florescent signal was observed in the foam cells treated with Ham-BODIPY (Supplementary Figure S3B), whereas the fluorescent signal was observed not only in the lipid droplets but also in the other cell components. This was also observed in the non-foam cells treated with Ham-BODIPY. Although the chemical properties of [ $\left.{ }^{99 \mathrm{~m}} \mathrm{Tc}\right] \mathrm{Tc}-\mathrm{BOD}$ and Ham-BODIPY presumed from the HPLC analysis were different (Figure 1 and Supplementary Figure S1), this result may correlate with the non-specific accumulation of [ $\left.{ }^{99 \mathrm{~m}} \mathrm{Tc}\right] \mathrm{Tc}-\mathrm{BOD}$ in the non-foam cells (Figure 2A). Therefore, we are now trying to optimize ${ }^{99 \mathrm{~m}}$ Tc-labeled BODIPY probes for achieving more specific imaging of lipid droplets.

\section{Materials and Methods}

\subsection{General}

All reagents were obtained commercially and used without further purification unless otherwise indicated. $\left[{ }^{99 \mathrm{~m}} \mathrm{Tc}\right] \mathrm{NaTcO}_{4}$ was purchased from Nihon Medi-Physics Co., Ltd. (Tokyo, Japan). W-Prep 2XY (Yamazen, Osaka, Japan) was used for silica gel column chromatography on a Hi Flash silica gel column $\left(40 \mu \mathrm{m}, 60 \AA\right.$, Yamazen). ${ }^{1} \mathrm{H}-\mathrm{NMR}$ and ${ }^{13} \mathrm{C}$-NMR spectra were recorded on a JNM-ECS400 (JEOL, Tokyo, Japan) with tetramethylsilane as an internal standard. Coupling constants are reported in hertz. Multiplicity was defined as singlet (s), doublet (d), or multiplet (m). Mass spectra were obtained using a SHIMADZU LCMS-2020 (SHIMADZU, Kyoto, Japan). RP-HPLC was performed with a Shimadzu system (SHIMADZU, an LC-20AT pump with an SPD-20A UV detector, $\lambda=254 \mathrm{~nm}$ ) with a Cosmosil $\mathrm{C}_{18}$ column (Nacalai Tesque, Kyoto, Japan, 5C $\mathrm{C}_{18}$-AR-II, diameter: $4.6 \mathrm{~mm}$, length: $150 \mathrm{~mm}$, particle size: $5 \mu \mathrm{m}$, pore size: $120 \AA$ ).

\subsection{Chemistry}

\subsubsection{Synthesis of $\mathbf{1}$}

Trifluoroacetic acid (TFA) $(30 \mu \mathrm{L})$ and 2,4-dimethylpyrrole $(1.00 \mathrm{~g}, 10.5 \mathrm{mmol})$ were added to a solution of 4 -formylbenzonitrile $(655 \mathrm{mg}, 5 \mathrm{mmol})$ in dichloromethane $(40 \mathrm{~mL})$. The reaction mixture was stirred at room temperature for $6 \mathrm{~h}$. To the reaction mixture, 2,3-dichloro-5,6-dicyano-p-benzoquinone (DDQ) (1.14 g, $5 \mathrm{mmol}), \mathrm{N}, \mathrm{N}$-diisopropylethylamine (DIEPA) $(10 \mathrm{~mL})$, and boron trifluoride diethyl ether complex were added. The reaction mixture was then stirred at room temperature overnight. After the addition of water $(80 \mathrm{~mL})$, the mixture was extracted with dichloromethane $(40 \mathrm{~mL} \times 2)$. The organic layers were combined, dried over $\mathrm{MgSO}_{4}$, and filtered. Evaporation of the filtrate resulted in the formation of a residue, which was purified using silica gel chromatography (chloroform/hexane = 3/2) to give $313 \mathrm{mg}$ of $\mathbf{1}\left(18 \%\right.$ yield). ${ }^{1} \mathrm{H}-\mathrm{NMR}\left(400 \mathrm{MHz}, \mathrm{CDCl}_{3}\right) \delta 1.36(\mathrm{~s}, 6 \mathrm{H}), 2.56(\mathrm{~s}, 6 \mathrm{H}), 6.01(\mathrm{~s}, 2 \mathrm{H})$, $7.47(\mathrm{~d}, J=8.0 \mathrm{~Hz}, 2 \mathrm{H}), 7.82(\mathrm{~d}, J=8.0 \mathrm{~Hz}, 2 \mathrm{H}) .{ }^{13} \mathrm{C}-\mathrm{NMR}\left(100 \mathrm{MHz}, \mathrm{CDCl}_{3}\right) \delta 14.6(4 \mathrm{C}), 113.2(2 \mathrm{C})$, 118.1 (1C), 121.8 (2C), 129.3 (2C), 130.7 (1C), 132.9 (2C), 138.6 (1C), 140.0 (2C), 142.5 (2C), 156.5 (2C). MS (ESI, pos) $m / z 350.2[\mathrm{M}+\mathrm{H}]^{+}$. 


\subsubsection{Synthesis of $\mathbf{2}$ (Ham-BODIPY)}

Hydroxylamine hydrochloride ( $188 \mathrm{mg}, 2.7 \mathrm{mmol})$ and triethylamine $(374 \mu \mathrm{L}, 2.7 \mathrm{mmol})$ were added to a solution of $\mathbf{1}(313 \mathrm{mg}, 0.9 \mathrm{mmol})$ in ethanol $(20 \mathrm{~mL})$. The reaction mixture was heated to reflux overnight. After the addition of water $(60 \mathrm{~mL})$, the mixture was extracted with chloroform $(60 \mathrm{~mL} \times 2)$. The organic layers were combined, dried over $\mathrm{MgSO}_{4}$, and filtered. Evaporation of the filtrate gave a residue, which was purified by silica gel chromatography (ethyl acetate/hexane $=9 / 1$ ) to give $187 \mathrm{mg}$ of 2 (Ham-BODIPY) (54\% yield). ${ }^{1} \mathrm{H}-\mathrm{NMR}$ ( $400 \mathrm{MHz}$, dimethyl sulfoxide (DMSO)- $d_{6}$ ) $\delta 1.38(\mathrm{~s}, 6 \mathrm{H}), 2.46(\mathrm{~s}, 6 \mathrm{H}), 5.95(\mathrm{~s}, 2 \mathrm{H}), 6.19(\mathrm{~s}, 2 \mathrm{H}), 7.38(\mathrm{~d}, J=8.4 \mathrm{~Hz}, 2 \mathrm{H}), 7.88(\mathrm{~d}, J=8.4 \mathrm{~Hz}, 2 \mathrm{H})$, $9.81(\mathrm{~s}, 1 \mathrm{H}) .{ }^{13} \mathrm{C}-\mathrm{NMR}\left(100 \mathrm{MHz}, \mathrm{DMSO}-d_{6}\right) \delta 14.1(2 \mathrm{C}), 14.2(2 \mathrm{C}), 121.4(2 \mathrm{C}), 126.0(2 \mathrm{C}), 127.7(2 \mathrm{C})$, 130.6 (2C), 133.9 (1C), 134.4 (2C), 141.6 (1C), 142.7 (1C), 150.0 (2C), 154.9 (2C). High-resolution (HR)-MS (FAB, pos) $m / z$ calcd. 383.1855, found $383.1858[\mathrm{M}+\mathrm{H}]^{+}$.

\subsubsection{Synthesis of 3}

To a solution of $2(104 \mathrm{mg}, 0.30 \mathrm{mmol})$ in DMSO (10 mL), 1,1-carbonyldiimidazole (58 mg, $0.36 \mathrm{mmol}$ ) was added. The reaction mixture was stirred and heated gradually from room temperature to $95^{\circ} \mathrm{C}$ for $6 \mathrm{~h}$. The reaction mixture was lyophilized and purified by silica gel chromatography (chloroform/methanol $=9 / 1)$ to give $46 \mathrm{mg}$ of $3\left(42 \%\right.$ yield). ${ }^{1} \mathrm{H}-\mathrm{NMR}\left(400 \mathrm{MHz}, \mathrm{CDCl}_{3}\right) \delta 1.38(\mathrm{~s}, 6 \mathrm{H})$, $2.56(\mathrm{~s}, 6 \mathrm{H}), 5.99(\mathrm{~s}, 1 \mathrm{H}), 7.10(\mathrm{~s}, 1 \mathrm{H}), 7.42(\mathrm{~d}, J=8.4 \mathrm{~Hz}, 2 \mathrm{H}), 8.03(\mathrm{~d}, J=8.4 \mathrm{~Hz}, 2 \mathrm{H}) .{ }^{13} \mathrm{C}-\mathrm{NMR}(100 \mathrm{MHz}$, $\mathrm{CDCl}_{3}$ ) $814.6(4 \mathrm{C}), 121.5(2 \mathrm{C}), 125.2(1 \mathrm{C}), 126.9$ (2C), $128.4(1 \mathrm{C}), 128.5$ (1C), 129.0 (2C), $131.0(1 \mathrm{C}), 138.5$ (2C), 139.9 (1C), 142.8 (2C), 156.0 (2C). MS (ESI, pos) $\mathrm{m} / z$ 409.2 [M + H] $]^{+}$.

\subsubsection{Synthesis of 4}

Iodomethane ( $86 \mu \mathrm{L}, 1.38 \mathrm{mmol})$ and potassium carbonate $(95 \mathrm{mg}, 0.69 \mathrm{mmol})$ were added to a solution of 3 (94 mg, $0.23 \mathrm{mmol})$ in $\mathrm{N}, \mathrm{N}$-dimethylformamide (DMF) $(20 \mathrm{~mL})$. The reaction mixture was stirred at room temperature for $3 \mathrm{~h}$. After the addition of water $(50 \mathrm{~mL})$, the mixture was extracted with chloroform $(30 \mathrm{~mL} \times 2)$. The organic layers were combined, dried over $\mathrm{MgSO}_{4}$, and filtered. Evaporation of the filtrate gave a residue, which was purified by silica gel chromatography (chloroform/methanol = 9/1) to give $57 \mathrm{mg}$ of 4 (58\% yield). ${ }^{1} \mathrm{H}-\mathrm{NMR}\left(400 \mathrm{MHz}, \mathrm{CDCl}_{3}\right) \delta 1.38(\mathrm{~s}, 6 \mathrm{H})$, $2.56(\mathrm{~s}, 6 \mathrm{H}), 3.39(\mathrm{~s}, 3 \mathrm{H}), 6.02(\mathrm{~s}, 2 \mathrm{H}), 7.54(\mathrm{~d}, J=8.4 \mathrm{~Hz}, 2 \mathrm{H}), 7.80(\mathrm{~d}, J=8.4 \mathrm{~Hz}, 2 \mathrm{H}) .{ }^{13} \mathrm{C}-\mathrm{NMR}(100 \mathrm{MHz}$, $\mathrm{CDCl}_{3}$ ) 814.5 (2C), $14.6(2 \mathrm{C}), 29.9$ (1C), 121.7 (1C), $124.0(2 \mathrm{C}), 128.2$ (1C), 128.8 (2C), $129.4(2 \mathrm{C}), 139.0$ (1C), 139.2 (1C), 142.5 (1C), 156.3 (2C), 158.0 (2C), 159.5 (2C). MS (ESI, pos) $m / z 423.2[\mathrm{M}+\mathrm{H}]^{+}$.

\subsubsection{Synthesis of $\mathbf{5}$ (MHam-BODIPY)}

A solution of $4(43 \mathrm{mg}, 0.10 \mathrm{mmol})$ in $1 \mathrm{M} \mathrm{NaOH}(\mathrm{aq}) / \mathrm{DMF}(1 / 1,20 \mathrm{~mL})$ was stirred at $95{ }^{\circ} \mathrm{C}$ for $14 \mathrm{~h}$. The reaction mixture was neutralized with $1 \mathrm{M} \mathrm{HCl} \mathrm{(aq)} \mathrm{while} \mathrm{being} \mathrm{cooled} \mathrm{in} \mathrm{an} \mathrm{ice}$ bath. After extraction with chloroform, the organic layers were combined, dried over $\mathrm{MgSO}_{4}$, and filtered. The filtrate was concentrated, and the residue was purified by silica gel chromatography (chloroform/methanol $=9 / 1$ ) to give $18 \mathrm{mg}$ of $5\left(41 \%\right.$ yield). ${ }^{1} \mathrm{H}-\mathrm{NMR}\left(400 \mathrm{MHz}, \mathrm{DMSO}-d_{6}\right) \delta 1.38$ $(\mathrm{s}, 6 \mathrm{H}), 2.46(\mathrm{~s}, 6 \mathrm{H}), 2.60(\mathrm{~d}, J=5.2 \mathrm{~Hz}, 3 \mathrm{H}), 5.87(\mathrm{~m}, 1 \mathrm{H}), 6.20(\mathrm{~s}, 2 \mathrm{H}), 7.42(\mathrm{~d}, J=8.0 \mathrm{~Hz}, 2 \mathrm{H}), 7.80$ $(\mathrm{d}, J=8.0 \mathrm{~Hz}, 2 \mathrm{H}), 9.68(\mathrm{~s}, 1 \mathrm{H}) .{ }^{13} \mathrm{C}-\mathrm{NMR}\left(100 \mathrm{MHz}, \mathrm{DMSO}-d_{6}\right) \delta 14.0(2 \mathrm{C}), 14.2(2 \mathrm{C}), 30.3(1 \mathrm{C}), 121.5$ (1C), 127.8 (2C), 129.1 (2C), 130.6 (1C), 133.4 (2C), 134.4 (2C), 141.4 (1C), 142.7 (1C), 154.8 (2C), 155.0 (2C). HR-MS (FAB, pos) $m / z$ calcd. 397.2011, found $397.2016[\mathrm{M}+\mathrm{H}]^{+}$.

\subsection{Radiolabeling}

To a solution of 2 (Ham-BODIPY) or 5 (MHam-BODIPY) $(1 \mathrm{mg}$ ) in an acetic acid/ethanol mixture $(1 / 4,100 \mu \mathrm{L}), 100 \mu \mathrm{L}$ of $\left[{ }^{99 m} \mathrm{Tc}\right] \mathrm{NaTcO}_{4}$ solution $(37 \mathrm{MBq})$ and $30 \mu \mathrm{L}$ of tin(II) tartrate hydrate solution ( $2 \mathrm{mg}$ of tin(II) tartrate hydrate $(7.5 \mu \mathrm{mol})$ dissolved in water $(2.5 \mathrm{~mL})$ ) were added. The reaction mixture was incubated at room temperature for $10 \mathrm{~min}$ and purified by RP-HPLC on a Cosmosil 5C 18 -AR-II column (Nacalai Tesque, diameter: $4.6 \mathrm{~mm}$, length: $150 \mathrm{~mm}$, particle size: $5 \mu \mathrm{m}$, pore size: 
$120 \AA$ ) using the mobile phase (10 mM phosphate buffer (pH of 7.4)/acetonitrile $=60 / 40(0 \mathrm{~min})$ to 30/70 $(30 \mathrm{~min})$ ) at a flow rate of $1.0 \mathrm{~mL} / \mathrm{min}$. To acquire [ $\left.{ }^{99 \mathrm{~m}} \mathrm{Tc}\right] \mathrm{Tc}-\mathrm{BOD}$, the two main peaks (retention time: around 17 to $18 \mathrm{~min}$ and around 20 to $21 \mathrm{~min}$ ) were collected, combined, and then concentrated to remove acetonitrile. The mixture of those two fractions was used as [ ${ }^{99 \mathrm{~m}} \mathrm{Tc}$ ] Tc-BOD in the subsequent examination. As for [ ${ }^{99 \mathrm{~m}} \mathrm{Tc}$ ] Tc-MBOD, the main peak (retention time: around 20 to 21 min) was collected, then concentrated. The radiochemical yields of [ $\left.{ }^{99 \mathrm{~m}} \mathrm{Tc}\right] \mathrm{Tc}-\mathrm{BOD}$ and $\left[{ }^{99 \mathrm{~m}} \mathrm{Tc}\right] \mathrm{Tc}-\mathrm{MBOD}$ were calculated by dividing the radioactivity of the collected fraction (the mixture of the two peaks in the radiolabeling study of [ $\left.\left.{ }^{99 \mathrm{~m}} \mathrm{Tc}\right] \mathrm{Tc}-\mathrm{BOD}\right)$ by the radioactivity of the cludes measured before HPLC purification. The radiochemical purities were analyzed using RP-HPLC with the same method as the purification procedures.

\subsection{Preparation of Foam Cells}

Animal experiments were conducted in accordance with our institutional guidelines and approved by the Kyoto University Animal Care Committee. ddY mice were purchased from Japan SLC, Inc. (Shizuoka, Japan) and were housed with food and water supplied ad libitum under a 12-h light/12-h dark cycle. To serve as lipid droplet-rich model cells, we prepared mouse foam cells following a previously reported method [22]. In brief, 10\% thioglycolate medium (10 mL) was injected intraperitoneally to ddY mice (females, 5 weeks old). After being housed for 4 days, the mice were sacrificed and the peritoneal cavity was washed using an injection of phosphate-buffered saline (PBS) (pH of 7.4) (Nacalai Tesque, Kyoto, Japan) to isolate macrophages. The macrophages were plated on 6-well plates $\left(8 \times 10^{5}\right.$ cells/well) and incubated in Dulbecco's modified Eagle's medium (DMEM) (4500 mg/L of Glucose; Nacalai Tesque) supplemented with $10 \%$ fetal bovine serum and $100 \mathrm{U} / \mathrm{mL}$ of penicillin and streptomycin at $37^{\circ} \mathrm{C}$ in an atmosphere containing $5 \% \mathrm{CO}_{2}$ for $24 \mathrm{~h}$. After incubation, the medium was removed and acetyl low density lipoprotein (LDL) $(50 \mu \mathrm{g} / \mathrm{mL})$ was added to the new medium ( $2 \mathrm{~mL}$ ). Macrophages were incubated to form foam cells for $48 \mathrm{~h}$. The formation of foam cells was confirmed by Oil red $\mathrm{O}$ staining. After removing the medium and washing twice with $1 \mathrm{~mL}$ of PBS ( $\mathrm{pH}$ of 7.4), $2 \mathrm{~mL}$ of staining solution (Oil red $\mathrm{O} 1.8 \mathrm{mg} / \mathrm{mL}$ in 2-propanol/water = 3/2) was added to each well, and incubated at room temperature for $20 \mathrm{~min}$. The staining solution was removed, and cells were washed twice with $1 \mathrm{~mL}$ of PBS (pH of 7.4). Bright field images were obtained using FSX-100 (Olympus, Tokyo, Japan).

\subsection{In Vitro Cellular Uptake Study}

[ $\left.{ }^{99 \mathrm{~m}} \mathrm{Tc}\right] \mathrm{Tc}-\mathrm{BOD}$ (the mixtures of two isomers) or [ $\left.{ }^{99 \mathrm{~m}} \mathrm{Tc}\right] \mathrm{Tc}-\mathrm{MBOD}(37 \mathrm{kBq}, 2 \mathrm{~mL}$ in DMEM supplemented with $0.1 \%$ DMSO) was added to foam cells or non-foam cells cultured in 6-well plates $(n=6)$, and the plates were incubated at $37^{\circ} \mathrm{C}$ in an atmosphere containing $5 \% \mathrm{CO}_{2}$ for $2 \mathrm{~h}$. After incubation, each well was washed with $1 \mathrm{~mL}$ of PBS (pH of 7.4) and the cells were lysed with $1 \mathrm{M}$ $\mathrm{NaOH}(0.2 \mathrm{~mL} \times 2)$. The radioactivity of the cells was measured using a $\gamma$ counter (Wallac 2470 Wizard; PerkinElmer, Waltham, MA, USA). The protein concentration was measured using a bicinchoninic acid protein assay kit (Thermo Fisher Scientific, Waltham, MA, USA).

\subsection{Stability in Murine Plasma}

[99m $\mathrm{Tc}] \mathrm{Tc}-\mathrm{BOD}$ (the mixtures of two isomers; $740 \mathrm{kBq}$ ) was added to freshly prepared murine plasma $(200 \mu \mathrm{L})$ collected from ddY mice (male, 5 weeks old). After incubating the solution at $37^{\circ} \mathrm{C}$ for $6 \mathrm{~h}$, acetonitrile $(200 \mu \mathrm{L})$ was added. Subsequently, the solution was centrifuged $(4,000 \mathrm{~g}, 5 \mathrm{~min})$ and the supernatant was analyzed using RP-HPLC. The analytical method of RP-HPLC was the same as that described in the radiolabeling section.

\subsection{In Vivo Biodistribution}

Male ddY mice (5 weeks old) were purchased from Japan SLC. Inc. (Shizuoka, Japan). [ ${ }^{99 \mathrm{~m}} \mathrm{Tc}$ ]Tc-BOD (the mixtures of two isomers) $(480 \mathrm{kBq}, 200 \mu \mathrm{L}$ in saline supplemented with $0.1 \%$ 
DMSO) was injected into ddY mice via the tail vein. After injection, the mice were sacrificed at $0.5,1,3$, or $6 \mathrm{~h}$ post-injection $(n=5$, per time-point). The blood was collected, organs of interest (blood, spleen, pancreas, stomach, intestine, kidney, liver, heart, and lung) were dissected and weighed, and the radioactivity in each organ or tissue was measured using a $\gamma$ counter (PerkinElmer). The results are expressed as a percentage of the injected dose per gram $(\% \mathrm{ID} / \mathrm{g})$ for the selected organs, except the stomach whose result is expressed as a percentage of the injected dose (\%ID).

\subsection{Statistics}

The student's $t$-test was used to assess the significance of differences. Differences at the $95 \%$ confidence level $(p<0.05)$ were considered significant.

\section{Conclusions}

In this study, we developed [ $\left.{ }^{99 m} \mathrm{Tc}\right] \mathrm{Tc}-\mathrm{BOD}$ and $\left[{ }^{99 \mathrm{~m}} \mathrm{Tc}\right] \mathrm{Tc}-\mathrm{MBOD}$ as novel BODIPY-based probes radiolabeled with ${ }^{99 \mathrm{~m}} \mathrm{Tc}$. [ $\left.{ }^{99 \mathrm{~m}} \mathrm{Tc}\right] \mathrm{Tc}-\mathrm{BOD}$ exhibited higher accumulation in foam cells and suitable properties for in vivo imaging. Thus, the $\left[{ }^{99 m} \mathrm{Tc}\right] \mathrm{Tc}-\mathrm{BOD}$ may have potential as an imaging probe to detect lipid droplets.

Supplementary Materials: The Supplementary Materials are available online.

Author Contributions: Conceptualization, Y.S. and M.O.; Data curation, Y.S. and K.T.; Formal analysis, Y.S., K.T., S.I., H.W., H.S. and M.O.; Funding acquisition, M.O.; Investigation, Y.S., K.T., S.I., H.W., H.S. and M.O.; Methodology, K.T.; Project administration, Y.S. and M.O.

Funding: This study was supported in part by a scholarship donation from Shionogi \& Co., Ltd.

Conflicts of Interest: The authors declare no conflict of interest.

\section{References}

1. Knopp, R.H. Drug treatment of lipid disorders. N. Engl. J. Med. 1999, 341, 498-511. [CrossRef]

2. Assy, N.; Kaita, K.; Mymin, D.; Levy, C.; Rosser, B.; Minuk, G. Fatty infiltration of liver in hyperlipidemic patients. Dig. Dis. Sci. 2000, 45, 1929-1934. [CrossRef] [PubMed]

3. Ross, R. Cell biology of atherosclerosis. Annu. Rev. Physiol. 1995, 57, 791-804. [CrossRef]

4. Cohen, J.C.; Horton, J.D.; Hobbs, H.H. Human fatty liver disease: Old questions and new insights. Science 2011, 332, 1519-1523. [CrossRef]

5. Falk, E.; Shah, P.K.; Fuster, V. Coronary plaque disruption. Circulation 1995, 92, 657-671. [CrossRef] [PubMed]

6. Greenberg, A.S.; Coleman, R.A.; Kraemer, F.B.; McManaman, J.L.; Obin, M.S.; Puri, V.; Yan, Q.-W.; Miyoshi, H.; Mashek, D.G. The role of lipid droplets in metabolic disease in rodents and humans. J. Clin. Invest. 2011, 121, 2102-2110. [CrossRef] [PubMed]

7. Fujimoto, T.; Ohsaki, Y.; Cheng, J.; Suzuki, M.; Shinohara, Y. Lipid droplets: a classic organelle with new outfits. Histochem. Cell Bio. 2008, 130, 263-279. [CrossRef]

8. Gluchowski, N.L.; Becuwe, M.; Walther, T.C.; Farese, R.V., Jr. Lipid droplets and liver disease: From basic biology to clinical implications. Nat. Rev. Gastroenterol. Hepatol. 2017, 14, 343-355. [CrossRef]

9. Stary, H.C.; Chandler, A.B.; Dinsmore, R.E.; Fuster, V.; Glagov, S.; Insull, W., Jr.; Rosenfeld, M.E.; Schwartz, C.J.; Wagner, W.D.; Wissler, R.W. A definition of advanced types of atherosclerotic lesions and a histological classification of atherosclerosis: A report from the Committee on Vascular Lesions of the Council on Arteriosclerosis, American Heart Association. Circulation 1995, 92, 1355-1374. [CrossRef]

10. Walther, T.C.; Farese, R.V., Jr. Lipid droplets and cellular lipid metabolism. Annu. Rev. Biochem. 2012, 81, 687-714. [CrossRef]

11. Davies, L.H.; Kasten, B.B.; Benny, P.D.; Arrowsmith, R.L.; Ge, H.; Pascu, S.I.; Botchway, S.W.; Clegg, W.; Harrington, R.W.; Higham, L.J. Re and 99m Tc complexes of BodP 3-multi-modality imaging probes. Chem. Commun. 2014, 50, 15503-15505. [CrossRef]

12. Listenberger, L.L.; Studer, A.M.; Brown, D.A.; Wolins, N.E. Fluorescent Detection of Lipid Droplets and Associated Proteins. Curr. Protoc. Cell Biol. 2016, 71, 4.31.1-4.31.14.

13. Pysz, M.A.; Gambhir, S.S.; Willmann, J.K. Molecular imaging: Current status and emerging strategies. Clin. Radiol. 2010, 65, 500-516. [CrossRef] [PubMed] 
14. Iwaki, S.; Hokamura, K.; Ogawa, M.; Takehara, Y.; Muramatsu, Y.; Yamane, T.; Hirabayashi, K.; Morimoto, Y.; Hagisawa, K.; Nakahara, K.; et al. A design strategy for small molecule-based targeted MRI contrast agents: their application for detection of atherosclerotic plaques. Org. Biomol. Chem. 2014, 12, 8611-8618. [CrossRef] [PubMed]

15. Ceulemans, M.; Nuyts, K.; De Borggraeve, W.M.; Parac-Vogt, T.N. Gadolinium (III)-DOTA complex functionalized with BODIPY as a potential bimodal contrast agent for MRI and optical imaging. Inorganics 2015, 3, 516-533. [CrossRef]

16. Nakayama, M.; Saigo, H.; Kai, E.; Koda, A.; Ozeki, H.; Harada, K.; Sugii, A.; Tomiguchi, S.; Kojima, A.; Hara, M. Hydroxamamide as a chelating moiety for the preparation of ${ }^{99 \mathrm{~m}}$ Tc radiopharmaceuticals (I). Nucl. Med. Commun. 1992, 13, 445-449. [CrossRef] [PubMed]

17. Nakayama, M.; Saigo, H.; Koda, A.; Ozeki, K.; Harada, K.; Sugii, A.; Tomiguchi, S.; Kojima, A.; Hara, M.; Nakashima, R. Hydroxamamide as a chelating moiety for the preparation of ${ }^{99 \mathrm{~m}} \mathrm{Tc}$ radiopharmaceuticals-II. The ${ }^{99 \mathrm{~m}}$ Tc complexes of hydroxamanide derivatives. Appl. Radiat. Isotopes 1994, 45, 735-740. [CrossRef]

18. Nakayama, M.; Xu, L.; Koga, Y.; Harada, K.; Sugii, A.; Nakayama, H.; Tomiguchi, S.; Kojima, A.; Ohyama, Y.; Takahashi, M. Hydroxamamide as a chelating moiety for the preparation of ${ }^{99 \mathrm{~m}}$ Tc-radiopharmaceuticals III. Characterization of various ${ }^{99 \mathrm{~m}} \mathrm{Tc}$-hydroxamamides. Appl. Radiat. Isotopes. 1997, 48, 571-577. [CrossRef]

19. Iikuni, S.; Ono, M.; Watanabe, H.; Matsumura, K.; Yoshimura, M.; Harada, N.; Kimura, H.; Nakayama, M.; Saji, H. Enhancement of binding affinity for amyloid aggregates by multivalent interactions of 99m Tc-hydroxamamide complexes. Mol. Pharm. 2014, 11, 1132-1139. [CrossRef]

20. Thipyapong, K.; Uehara, T.; Tooyama, Y.; Braband, H.; Alberto, R.; Arano, Y. Insight into technetium amidoxime complex: oxo technetium $(\mathrm{V})$ complex of $\mathrm{N}$-substituted benzamidoxime as new basic structure for molecular imaging. Inorg. Chem. 2011, 50, 992-998. [CrossRef]

21. Iikuni, S.; Ono, M.; Watanabe, H.; Yoshimura, M.; Ishibashi-Ueda, H.; Ihara, M.; Saji, H. Novel Bivalent 99m Tc-Complex with N-Methyl-Substituted Hydroxamamide as Probe for Imaging of Cerebral Amyloid Angiopathy. PLoS ONE 2016, 11, e0163969. [CrossRef] [PubMed]

22. Ogawa, M.; Nakamura, S.; Saito, Y.; Kosugi, M.; Magata, Y. What can be seen by ${ }^{18}$ F-FDG PET in atherosclerosis imaging? The effect of foam cell formation on ${ }^{18}$ F-FDG uptake to macrophages in vitro. J. Nucl. Med. 2012, 53, 55-58. [CrossRef] [PubMed]

23. Lee, S.J.; Thien Quach, C.; Jung, K.-H.; Paik, J.-Y.; Lee, J.H.; Park, J.W.; Lee, K.-H. Oxidized low-density lipoprotein stimulates macrophage ${ }^{18}$ F-FDG uptake via hypoxia-inducible factor-1a activation through Nox2-dependent reactive oxygen species generation. J. Nucl. Med. 2014, 55, 1699-1705. [CrossRef] [PubMed]

24. Xu, L.C.; Nakayama, M.; Harada, K.; Nakayama, H.; Tomiguchi, S.; Kojima, A.; Takahashi, M.; Arano, Y. Synthesis and evaluation of hydroxamamide-based tetradentate ligands as a new class of thiol-free chelating molecules for ${ }^{99} \mathrm{~m}$ Tc radiopharmaceuticals. Nucl. Med. Biol. 1998, 25, 295-303. [CrossRef]

25. Shimizu, Y.; Kuge, Y. Recent Advances in the Development of PET/SPECT Probes for Atherosclerosis Imaging. Nucl. Med. Mol. Imaging 2016, 50, 284-291. [CrossRef] [PubMed]

26. Liu, S.; Lin, T.P.; Li, D.; Leamer, L.; Shan, H.; Li, Z.; Gabbai, F.P.; Conti, P.S. Lewis acid-assisted isotopic ${ }^{18} \mathrm{~F}-{ }^{19} \mathrm{~F}$ exchange in BODIPY dyes: facile generation of positron emission tomography/fluorescence dual modality agents for tumor imaging. Theranostics 2013, 3, 181-189. [CrossRef] [PubMed]

27. Hendricks, J.A.; Keliher, E.J.; Wan, D.; Hilderbrand, S.A.; Weissleder, R.; Mazitschek, R. Synthesis of $\left[{ }^{18}\right.$ F]BODIPY: bifunctional reporter for hybrid optical/positron emission tomography imaging. Angew Chem. Int. Ed. Engl. 2012, 51, 4603-4606. [CrossRef]

28. Ono, M.; Watanabe, H.; Ikehata, Y.; Ding, N.; Yoshimura, M.; Sano, K.; Saji, H. Radioiodination of BODIPY and its application to a nuclear and optical dual functional labeling agent for proteins and peptides. Sci. Rep. 2017, 7, 3337. [CrossRef] [PubMed]

29. Jennings, L.E.; Long, N.J. 'Two is better than one'-Probes for dual-modality molecular imaging. Chem. Commun. 2009, 3511-3524. [CrossRef] [PubMed]

Sample Availability: Samples of the compounds are not available from the authors. 